\title{
Civilizational Aspects of Japanese History: Continuities and Discontinuities
}

\author{
JÓHAN N PÁLL ÁRNASON*
}

Civilizační aspekty japonských dějin: Kontinuity a diskontinuity

\begin{abstract}
This paper discusses the merits and problems of civilizational perspectives on Japanese history, with particular reference to the task of combining a comparative approach with valid points made by those who see Japan as a highly self-contained cultural world. After a brief consideration of Claude Lévi-Strauss's reflections on Japan, the central section of the paper deals with Shmuel Eisenstadt's work. His conception of Japan as a distinctive civilization characterized by pre-axial patterns is rejected on the grounds that the native mode of thought which he proposes to describe is more plausibly interpreted as an offshoot of Chinese traditions, although a notably autonomous and historically changing one. The transmission of Daoism to Japan, although much less explicit than the reception of Confucianism and Buddhism, was of crucial importance. That said, Eisenstadt's concrete analyses of Japanese ways to transform foreign inputs are often detailed and insightful, and his comments on the relationship between culture and institutions raise important questions, although they must in many cases be reformulated in more historical terms. The paper discusses the genesis, dynamics and collapse of the Tokugawa regime (1600-1868), and concludes with reflections on Japanese modernity, up to and including its present crisis.
\end{abstract}

Keywords: Japan; civilization; culture; East Asia; China; S. N. Eisenstadt; Tokugawa regime; Japanese modernity

DOI: $10.14712 / 23363525.2021 .20$

At the beginning of the introduction to this issue, I quoted Eisenstadt's remark on Japan's exemplary importance for comparative historical sociology, and noted the multiple ramifications of that perspective. There is, however, another side to the matter. As a major authority on twentieth-century Japanese history puts it, "something about Japan invites people to view it hermetically", and the same author adds that "it is not just outsiders who tend to isolate and insulate the Japanese experience; no one makes more of a fetish of the supposed singularity of the national character and the national experience than the country's own cultural essentialists and neonationalists" [Dower 1999: 29]. The domestic version of the "hermetic" view, known as nihonjinron, has been a significant force in Japanese cultural life, and not without influence on political attitudes; it has also come in for extensive scholarly criticism, and will not be further discussed here. But it seems worthwhile to take a look at some prominent outsiders, with a view to the question of possible - and not necessarily all bad - interconnections of the hermetic and the comparative approaches. As will be seen, that kind of cross-reference is evident in Eisenstadt's

" Prof. Jóhann P. Árnason, Department of Historical Sociology, Faculty of Humanities, Charles University, Pátkova 2137/5, 18200 Praha 8. E-mail: J.Árnason@latrobe.edu.au 
work on Japanese civilization, with problematic but certainly not irrelevant results. To place the issue in broader context, we should start with more openly speculative and adventurous exercises.

\section{Thinking with Anthropologists}

The most widely known example of nihonjinron from the outside is without any doubt Ruth Benedict's The Crysanthemum and the Sword, first published in 1946. The most remarkable highlights of its subsequent career are the Japanese reactions, commonly seen as a very important step in the development of domestic discourses on uniqueness and continuity, and the success of a Chinese translation, coinciding with a downturn in relations between China and Japan. Criticisms of the book have demolished its basic premises and central claims [see e.g. Mouer - Sugimoto 1986; Lie 2001], and its attempt to grasp the cultural essence of Japaneseness is no longer a matter for serious debate. But for a proper perspective on the book as a historical phenomenon, the complex background to Benedict's work should be acknowledged. Although she wrote the book at the request of U.S. authorities preparing for the occupation of Japan, it is not at all a straightforward victor's guide to alien hearts and minds. Benedict was, as the title suggests, trying to bring together two very different aspects of the Western encounter with Japan: the aesthetic fascination that had been such a key element in late nineteenth- and early twentieth-century perceptions of Japan, and the subsequent experience of Japanese militarism. On another level, she drew on the record of cultural anthropology and on Oswald Spengler's morphology of culture; the combination of these sources enabled her to portray Japan as a self-contained cultural world, while avoiding Spengler's restrictive classification of high cultures and his excessive emphasis on one primal symbol for each of them (Spengler dismissed the very idea of Japanese culture in a footnote, suggesting that the culture of Japan had been Chinese and was now Western).

The search for anthropological foundations of the hermetic view did not cease with the dismissal of Benedict's work. A more recent but much less widely noticed variation on this theme was proposed by the most eminent anthropologist of the twentieth century, Claude Lévi-Strauss. His reflections on Japan certainly do not belong to the most seminal part of his work, but as I will try to show, they suggest some interesting perspectives on the issues to be discussed in relation to Eisenstadt's views. The two texts in question are a series of three lectures on anthropology and the modern world, delivered in Tokyo on the invitation of the Ishizaka Foundation in 1986, and a collection of occasional writings on Japan, both published posthumously in 2011; the title chosen for the latter book, "The Other Side of the Moon", says something about the overall approach [Lévi-Strauss 2011a, $2011 b]$. Here I will not stick closely to the texts; rather, thematic affinities between general anthropological observations and specifically Japanese questions will be singled out and linked to further discussion.

The general thrust of Lévi-Strauss's argument is perhaps best summed up in the following terms: "Like many other comparisons that one might make, that of Europe and Japan speaks against the notion of uni-directional progress" [Lévi-Strauss 2011a: 123]; "à sens unique" could perhaps also be read as "with the same meaning"; it is not just the uniformity, but also the unequivocal character of progress that is at stake). His specific 
strategy of comparison takes off from a critique of more commonplace views. The idea of affinities between European and Japanese feudalism is dismissed on the grounds that the military, dynamic and pragmatic spirit of the latter makes it a "perfectly original form of social organization" [Lévi-Strauss 2011a: 122], only superficially similar to the European case; the similarly widespread notion that Japan's escape from feudalism and the turn to modernization resulted from the opening to the West in the second half of the nineteenth century is rejected, on the grounds that technological developments, levels of literacy and commercial economy from the sixteenth century onwards testify to an early and indigenous dynamic of modernization.

These two points merit closer consideration. The first cannot be accepted at face value; militarism, dynamism and pragmatic attitudes were no less characteristic of European feudalism than of the Japanese variety. Lévi-Strauss was nevertheless on to something, but it must be expressed in different terms: as a contextual factor, rather than an intrinsic feature. The most salient aspect of Japanese feudal elites is their record of initiating new processes of state formation and redefining the relationship of their power centres to the pre-existing state; different arrangements of this dual power (asymmetric, yet not undisruptable) succeeded each other during the medieval period, but the crowning achievement was the early modern Tokugawa regime, more stable and more effectively centralized than any of its predecessors. As for Lévi-Strauss's second point, he is right to emphasize that Japan's road to modernity did not begin with the opening to the West, and that indigenous developments were at work in multiple fields of social life. But if the broader context and the specific connections between domestic and external forces are to be clarified, the trends and turns of state formation once again appear as a decisive factor. The foundation and consolidation of the Tokugawa regime set the scene for a very distinctive mode of growth and change. The unification of the country created preconditions for commercial integration, urbanization and cultural flowering; paradoxically, this went hand in hand with a far-reaching isolation from foreign contacts (exaggeratedly known as sakoku, the time of the closed country). The Tokugawa state might, in that regard, be described as a developmental container. Another paradox, even more puzzling, is the long-term pacification imposed by a military power elite after its most epoch-making victory, and the impact of this radical change on the social force most actively involved in it. The most prominent military families became local dynasties, but the numerous lower ranks of the samurai provided the personnel needed for administrative purposes on both central and domain levels. This bureaucratization of the samurai, as many historians have described it (at least in the sense that the middle and lower ranks were drawn into administrative roles), was one of the crucial preconditions for the transformation initiated in 1868 and consolidated during the following decades. But the Tokugawa period also saw the emergence of a new intelligentsia, largely from a samurai background.

The samurai input was essential to the activism that ensured a rapid break with the old regime, as well as to the selective leaning on traditions that helped to legitimize and stage-manage the new one. It also proved - despite the transformation of the samurai ethos during the centuries of isolation and pacification - remarkably conducive to the militaristic turn soon taken by the reconstructed Japanese state. These developments must be seen in a broader context of interrelations between tradition and modernity; to get a grasp on that problematic, it will be useful to return to Lévi-Strauss's reflections, and to take a closer look 
at the anthropological underpinnings of his approach to Japan. I will not try to recapitulate the whole of his ideas on Japan, nor to reconstruct any underlying unity of a rather disjointed train of thought; the points picked out here are chosen on the basis of their affinity with the civilizational issues to be discussed below.

The first presupposition to note has to do with a constitutive paradox of anthropology. This discipline affirms a fundamental equality of cultures, in the sense that it refrains from "intellectual or moral judgments on the respective values of such and such systems of belief or such and such forms of social organization" [Lévi-Strauss 2011a: 135]. To put it another way, cultural relativism is - as Lévi-Strauss explicitly states - an obligatory starting-point for anthropological research and theorizing. The other side of that is the anthropologist's acceptance of her or his own dependence on a specific cultural background, from which any proposed criteria of judgment will be derived. "Every culture ... is essentially incapable of making a true judgment on another culture, because a culture cannot escape itself" [Lévi-Strauss 2011a: 135], and notwithstanding modern anthropology's commitment to three universalizing projects (the ideal of scientific objectivity, the vision of a universal humanism going beyond the traditional Western understandings of that idea, and the quest for "authenticity" through a grasp of the subjective significance attributed to social phenomena), this relativizing principle also applies to its results. But that is not the whole story. The anthropologist can to a certain extent counterbalance or mitigate the constraints of relativism, and there are two particularly relevant ways of attempting that. Although it is impossible to rank human societies in terms of their place within a universal scheme of progress, comparative studies can reveal progress in specific fields and acknowledge the distinctive achievements of different cultures. When it comes to Japan, Lévi-Strauss is most inclined to stress the development of aesthetic sensibilities and their importance for nineteenth-century Western perceptions of Japan; seen from Europe, Japanese explorations in this domain appeared as guidances to further ventures.

The second way is more challenging, and it is the main justification for referring to a paradox of anthropology. If it is the case that an anthropologist, however aware of the intellectual standards of his discipline, is inescapably tied to the horizons of his culture and therefore unable to match the knowledge possessed by insiders of another culture, it may still be possible to take advantage of the outsider's position and attempt a kind of overview that is less accessible from within. Lévi-Strauss's reflections reveal that ambition, although they do not add up to any synthetic picture. Here I will only consider two observations, one specific and the other more comprehensive, but both conducive to further discussion along the lines indicated above.

At the beginning of his lecture on "the place of Japanese culture in the world", LéviStrauss introduces a theme that has, as he puts it, been equally decisive for his individual experience and his anthropological perception of Japan [Lévi-Strauss 2011b: 19-22]. It is the strong impression of a continuity between mythology and history. He recalls visits to Japanese shrines as confirming this intuition and contrasts them with less easily imaginable links to sacred history in the Holy Land (where, as he puts it, both his culture and his origins ought to have made him more sensible to such connections). Given the treatment of myths elsewhere in his work, there is no doubt that he sees this aspect of Japanese culture in a positive light; he is one of those who have tried to reveal the underlying rationality of myth and thus establish a continuity with more explicitly rational efforts in 
later history, even if his distinctive version of this view allows for more distance between archaic and advanced modes of thought than many others. It would be easy to object that twentieth-century Japanese history has cast a much less favourable light on the mythological legacy. The ideological constructs invoked to justify the self-destructive road taken by imperial Japan had a more outright mythological thrust than the European cases to which they are sometimes compared. But it might be more interesting to take a closer look at Lévi-Strauss's particular account of mythology's original meeting with history; it suggests some questions for further consideration and reveals problems inherent in the search for archaic sources of Japanese specificities (that line has, as will be seen, also proved tempting in other cases).

Lévi-Strauss refers to two landmark texts, the Kojiki and the Nihon shoki (assumed to have been compiled, respectively, in 712 and 720) and describes them as having "with incomparable art" [Lévi-Strauss 2011b: 24] both integrated universal themes of mythology and codified an enduring fusion of mythology and history; he adds that this achievement constitutes the fundamental problem of Japanese culture. How could it, despite its marginal geographical situation and long periods of isolation, accomplish a synthesis of elements that are elsewhere found only in more dispersed condition? On closer examination, these claims seem vastly exaggerated in regard to global significance and oversimplified inasmuch as they imply a self-contained cultural articulation. A contextualizing shift of focus will throw light on a constellation that is of great interest for comparative history, but in a sense very different from Lévi-Strauss's picture.

It is true that both texts aim at a synthesis of mythology and a historical narrative with legitimizing purposes, but not with the same relative weight. The mythological component is much stronger in the Kojiki. Another noteworthy difference is that the Nihon shoki is written in classical Chinese, the Kojiki in a mixture of Chinese and Japanese written with Chinese characters. This reflects - with different nuances - a Chinese connection, inseparable from the contemporaneous political construction of a relationship to China, and more generally to the East Asian cultural world. To quote the most widely read history of Japanese literature, "the compilers sought out fragmentary myths and stories originally transmitted in the provinces, interwove ballads known at court and among the people at large and embellished and organized the whole of this material through the medium of adopted figures of speech from China, historical formats similarly adopted and Confucian philosophy" [Kato 1990: 39]. However, the same author adds that "in the very way the stories are told the structure of the indigenous spirit emerges" [Katō 1990: 39]. The question whether - and in what sense - one can speak of a structure of the indigenous spirit must be posed, but will require a more extensive preparatory grounding. In the meantime, the historical context of the two compilations - the appropriation of local traditions in order to strengthen control over the provinces, the ideological and political ordering of relations with China, and the emergence of a court culture - should be noted; and one further aspect may be added. As recent scholarship [especially Ooms 2008] has shown, the joint codification of myth and history was an integral part of the political settlement that ended a conflict between two branches of the ruling dynasty. Dynastic continuity is often counted among the unique features of Japanese history, but one of the necessary qualifications is that it was twice troubled by violent intra-dynasty schisms, in the late seventh and - more lastingly - in the fourteenth century. The outcomes differed. The seventh-century crisis 
came to an end with the victory of Emperor Tenmu (673-686) and led to a strengthening of central power wielded by the imperial court, whereas the fourteenth-century one began with a rearguard action against the marginalization of the imperial court by military rulers, caused a temporary split into northern and southern courts, and concluded with a more massive disempowerment (but not de-legitimation) of the dynasty than before.

The unity of myth and history thus turns out to be an outcome of power struggles, a product of eclectic but purposeful ideological strategies, and a component of the long-lasting legitimizing framework that has helped to preserve - if not always to practice - a distinctive version of sacral rulership across multiple social and political upheavals. It is true that the divine genealogy of the Japanese imperial dynasty proved exceptionally resilient and conducive to elaboration, and there is - especially in the case of the Kojiki no denying the aesthetic appeal that transcends ideological uses and occasions. But to gain a long-term perspective on the limits as well as the potentialities and ambiguities of the texts in question, their later destinies must be taken into account. The two canonical works took shape at the same time and in the same environment, but their subsequent histories of reception were very different. The Nihon shoki, originally - at least according to some readings - intended for a Chinese audience, became a paradigm of court historiography and an essential point of departure for later chronicles. The Kojiki, though never forgotten, was strikingly neglected for a very long time, until it was rediscovered during the Tokugawa era, especially by Motoori Norinaga (1730-1801) and the kokugaku school inspired by him. Norinaga's work on the Kojiki made the text much more accessible, but it also reinforced archaic notions of divine origins and sacral dignity, which Norinaga took more literally than many of his contemporaries [Watanabe 2012: 229-252]. In the early modern context, these archaisms acquired new layers of meaning: in connection with the advancing process of nation formation, they supported the interconnected sacralization of dynasty, country and community that became a key feature of Japanese ultra-nationalism.

The unity of myth and history, invoked by Lévi-Strauss as a given and lasting legacy, is thus entangled in transformations, early as well as more recent ones, and a challenge rather than a premise for historical interpretation. Similar considerations apply to the other point to be noted; it has to do with a more general characterization of the Japanese experience. At the end of his 1986 lectures, Lévi-Strauss turns to reflections on cultural diversity and creativity. He claims - without any detailed argumentation - that the most creative epochs in history have been marked by communication across cultural distances; then he adds that modern humanity seems to have embarked on a road towards global civilization, and raises the question whether this trend would not lead to a self-impoverishing loss of diversity. He credits Japan with an exemplary history that might show the way to counteract the threat: "For centuries, Japan has maintained the equilibrium between two attitudes: at times it has been open to external influences and ready to absorb them; at times it has retired into itself, as it were to gain time to assimilate the contributions from outside and put its own mark on them" [Lévi-Strauss 2011: 140]. There is no doubt that this formulation stays too close to quasi-official visions of Japanese history. It is nevertheless hard to deny that a certain interplay of openings to the outside world (always conditional), withdrawals from it (never absolute), and transformations or reinventions of imported models (variously oriented) has been a striking and recurrent pattern. It remains to be seen whether we can describe it in less streamlined terms than those proposed by Lévi-Strauss. 
The first step is to emphasize that changing combinations of the three aspects are neither reducible to internal changes of course, nor simply a matter of cultural attitudes. They are always enframed in broader geopolitical constellations and restructurings. The epoch-making innovations of the seventh century (most directly associated with the Taika Reform of 646) were, not least, a response to changing configurations of power in the region. The reunification of China, the rise of the very vigorous and expansionist T'ang dynasty and the consolidation of a single state on the Korean peninsula added up to an unprecedentedly challenging environment and a compelling reason to accelerate state formation in Japan. The very different changes around 1600 were prompted by two geopolitical considerations: the war in Korea, launched by a Japanese invasion, threatened to spiral into unmanageable complications, and the complex balance of central and local rule imposed on the Japanese archipelago by the founders of the Tokugawa regime seemed vulnerable to conjunctions of separatist forces and foreign influences. As a result, the sakoku strategy of withdrawal and minimized contacts was adopted. Finally, the nineteenth-century opening was not simply a reaction to the immediate threat posed by the American warships arriving in 1853. Before that, the Japanese power elite and its potential rivals had been following the misfortunes of China at the hands of a superior Western power, and were well aware of the imperial dynamic behind the new arrivals in East Asia. There was, in other words, a global perspective that lent meaning and substance to the new orientation.

A second complicating aspect is that opening and closure do not simply alternate; rather, they recurrently but variously combine in ways of redefining Japan's relationship to the outside world. The seventh- and eighth-century transformation would have been unthinkable without a very sweeping cultural opening to the Chinese world. But at the same time, the architects of the transformation - an emerging dynastic clan allied with aristocrats and bearers of Chinese culture and Buddhism - constructed an image of closed identity, fundamentally important for later long-term developments. Several aspects of this complementary closure may be distinguished. The newly structured Japanese state was kept out of the Chinese "tributary" system of international relations, and from the later seventh century onwards, diplomatic contacts were kept at a minimal level. In relation to Chinese imperial authority, emphasis was placed on the equal dignity and distinctive divine origin of the Japanese rulers. A key move was the historical closure achieved through an official dynastic genealogy, embedded in a mythological and cosmological compendium; this was the ideological role of the texts mentioned above. Last but not least, the "invention of Japan" [Souyri 2010: 112] as a self-contained entity obscured the massive contribution of Korean immigrants, many of them refuges with special cultural and administrative qualifications from the peninsular states that were being conquered by the rising kingdom of Silla. This side of the story has only recently been taken into account by historians.

When closure predominates, as it did in the Tokugawa era from the early seventeenth century, it can be shown that certain kinds of opening were integral to the regime. A Dutch trading station ensured a minimal contact with Western outposts, and a gradual licence to gather knowledge about Europe made the country significantly better prepared for a later change of course. A further interesting feature of this era was an intensified reception of Confucian thought, important both in its own right and as a counterpole to the nativist ideas of the kokugaku school. This was a new phase of the opening to China, but at a distance and without any background or outlet in interstate relations. 
The Meiji restoration/revolution of 1868 is at first sight a paradigm case of radical opening. But further consideration of the background and the sequel suggests a more nuanced picture.

The activists who were to play a decisive mobilizing role in the final confrontation with the old regime had - in many cases - been involved in xenophobic protests against the impending concessions to foreign pressure (the so-called sonnō jōi movement); when it came to the crunch, that did not prevent them from supporting the new course of "seeking knowledge all over the world". However, the nativist imaginary of closure resurfaced in the course of stabilizing the Meiji regime. After some initial fluctuations, a particularly uncompromising type of nationalism emerged as the ideological framework of the new order. This was, as some critics put it, an attempt to make the nation the measure of all things. Maruyama Masao's classic analysis of "ultra-nationalism", as it developed from the 1890s to the Pacific War [Maruyama 1995], stressed the refusal to acknowledge any transcending claims to universal validity. Ultra-nationalist ideology was, in other words, a more closed universe of discourse and imagination than any other kind of nationalism.

The rise of modern Japanese nationalism and its road to disaster were intertwined with complex processes of modernizing change and empire-building. That brings us to the third aspect of Lévi-Strauss's supposedly recurrent pattern: the adaptation of cultural or institutional borrowings to Japanese contexts and traditions. Here the question to raise is whether the domestication or reinvention of imported models has also involved a problematic that became - in a longer run - acute enough to spark crises and transformations. The landmark developments discussed above merit closer examination from this point of view, beginning with the "japanized" version of Chinese-style sacred monarchy that took shape in the seventh and eighth centuries. Earlier scholarship on this subject was sometimes inclined to minimize the social impact of the new central institutions; but historians now seem largely in agreement that there was a determined and comprehensive attempt to establish central control, backed up by a strong monarchy and accomapnied by conquest of outlying regions of the archipelago. The drive for autocratic (some authors would say despotic) control was at its strongest under Emperor Tenmu (672-686). But the very vigour of the centralizing push was to activate trends that led to far-reaching restructurings of social power. Strict subordination was to be imposed on local officials and power-holders, but at the same time, they were entrusted with key roles in maintaining the regime centred on the imperial court (first in Nara and then in Kyoto). This is the context in which historians situate one of the most fundamental problem of Japanese history: how to explain the rise of the samurai? Proposed answers involve both armed retinues of court aristocrats and the growing power of local strongmen.

The early modern unification under a military regime differs from the archaic "invention of Japan" in fundamental respects. As noted above, the Tokugawa ascendancy was the culminating phase of internal processes, and the foundational arrangements did not draw on external models. We can nevertheless, with regard to the later history of the regime, speak of a certain interplay between borrowing and adaptation. One of the most interesting features of Tokugawa Japan is that despite the imposition of a rigid social and political order, "the boundaries of acceptable thought were only roughly defined and sporadically enforced" [Totman 1993: 160]. This intellectual flexibility enabled new departures in relation to Chinese thought. The starting-point was a closer study of the Neo-Confucian 
teachings that had developed (and to a certain extent spread to the larger Chinese world, especially Korea) since the eleventh and twelfth century; but this gave way to more autonomous readings of Confucian sources, described by historians of ideas as a naturalization of Confucianism, and including attempts to understand the very beginnings of that tradition better than the Chinese themselves had done. Reactions to such efforts led in turn to a revival of nativist thought that gradually reinforced the prestige of the imperial dynasty. Together with structural and geopolitical factors, and in response to an unprecedented external challenge, this ideological potential was to play a role in the demise of the Tokugawa regime, completed in 1868. Some aspects of that process will be discussed below, in connection with Eisenstadt's understanding of Japanese civilization.

The sequel to the Meiji restoration/revolution of 1868 was a new round of the interaction between opening and adaptation to domestic contexts. For the new regime, the most urgent task was to transform Japan into a state capable of holding its own and becoming a full-fledged actor in the global arena. This necessitated multiple modernizing drives: an industrialized economy, a fully centralized bureaucratic state, and an empire-building strategy were essential to survival and success (for the architects of the Meiji state, the lastnamed goal seems to have been an obvious implication of modern statehood). The initial signal for a distinctively Japanese framing of these projects was the claim to restore direct imperial rule. This was, on the face of it, a strikingly archaizing move; the last attempt to reassert the authority of the emperor against military rule had been made in the fourteenth century. Observers and historians of modern Japan have therefore often been tempted to dismiss this as a fiction, and to argue that bureaucrats or militarists were ruling behind the imperial façade. But matters were more complicated. The re-empowering of the emperor cannot be described as mere fiction; the most convincing counter-evidence is the role that the Shōwa emperor is now known to have played in the militarist turn of the 1930s and the subsequent war. Not that he ever achieved or aspired to autocratic power; but in the context of the decision-making machinery, his position was a unique and significant one, however difficult it may be to define in precise conceptual terms. In this regard, Ian Kershaw's study of major strategic decisions during World War II is illuminating [Kershaw 2008]. In comparison with the other cases analyzed in that book (Britain, Germany, Italy, the Soviet Union and the United States), there is no doubt that the Japanese decision to "strike south" comes across as the most opaque. Japan's interwar political regime, especially after 1930, has often - and for good reasons - been labelled a faction-ridden oligarchy; this would have been enough to complicate decision-making, but the half-absent presence of the emperor made the situation a good deal more confused. Because of his divine aura, he could neither intervene directly as a party to the process, nor abstain from incarnating ultimate authority.

The imaginary but not fictitious institution of direct imperial rule was doubly important. On a formal level, it was enshrined in the Meiji constitution of 1890, where sovereignty was attributed to a dynasty of divine origin. During the preparatory debate on constitutional issues, Itō Hirobumi - at the time Japan's most influential statesman - had argued that the only possible Japanese way to match the stabilizing role of Christianity in Western societies was to rely on myths and cults linked to the imperial dynasty. The perpetuation or at least partial defence of dynastic sovereignty was not unknown in the European state system, but the legitimation through divine descent was uniquely Japanese. Moreover, 
direct subordination of the military - and the corresponding ministry - to the emperor enhanced his supremacy.

It is generally taken for granted that the constitution-makers did not literally believe in the divinity of the dynasty. But it does not follow that they were only interested in political expediency. They took the mythology of the imperial institution seriously as a symbol of enduring identity and historical continuity, hence of a national self-image to which they were committed. In this sense, the ideological significance of the imperial centre transcended its formal role.

\section{Eisenstadt's Image of Japan}

As noted above, the notion of Japanese uniqueness has been a key component of the nationalist discourses on identity, but open to significant variations. Lévi-Strauss's reflections are strongly connoted by an outsider's vision of uniqueness, albeit of a markedly impressionistic kind. The most systematic attempt to construct a theory of Japanese uniqueness, not just from the outside but in the context of explicit world-historical comparison, is to be found in Shmuel Eisenstadt's book on Japanese civilization [Eisenstadt 1996]. This work is also the most sustained combination of comparative and hermetic approaches (the latter to be understood in the metaphorical sense outlined above with a reference to Dower); and in that context, we can reframe some issues touched upon by Lévi-Strauss.

As we have seen, the hermetic approach can never be completely separated from comparative references; but to acknowledge a minimal and sometimes implicit dependence is one thing, to elaborate a balanced synthesis is another, and projects of the latter kind need both general considerations and adjustment to particular cases. For historical sociology, the comparative aspect is fundamental and indispensable. The idea that "entangled history" (Verflechtungsgeschichte) should replace comparative perspectives, as occasionally suggested in recent years, seems based on an elementary mistake: the analysis of processes unfolding across national, cultural or regional boundaries can never do without comparison of their impact in different settings. But a more detailed clarification of the hermetic angle and its specific relevance to Japan is in order. If the primary meaning of the term suggests a closed frame of reference and interpretations in terms of internal connections, the first association with Japan might be the strikingly autonomous reworking of institutional models, ideas and cultural orientations coming from outside. That applies to the great seventh- and eighth-century transformation as well as to the modernizing changes after 1868. Even the foreign-controlled reforms after 1945, at first so little autonomous that the label "neo-colonial revolution" [Dower 1999] has been used to describe them, eventually gave rise to a socio-economic regime very different from American notions of modern capitalism; it came to be perceived as a rival to the erstwhile occupying power, and considerable pressure was exercised in order to bring it closer to supposedly correct standards. But although these episodes reflect a marked ability to domesticate and redefine inputs from elsewhere, they involved massive (and in the last case very asymmetric) interaction with the outside world. A more self-contained pattern of development will be evident if we take a closer look at the long trajectory between changes induced by contacts with China and Korea and those triggered by a momentous encounter with the West. Over 
more than four centuries, from the late twelfth to the early seventeenth, Japan underwent a complex and ramified process of state reformation, beginning with the establishment of a power centre controlled by a military elite, separate from the imperial court, and culminating in the unification of the country under a more effectively centralized military regime and a long-lasting marginalization of the court and the dynasty in Kyoto. In between, the struggles for power had led to a short-lived but spectacular attempt to restore imperial rule, followed by a new military takeover and then a disintegration into multiple warring domains, including - briefly - a power bloc of Buddhist monasteries. The whole process was essentially a matter of internal dynamics; comparable long-drawn-out upheavals elsewhere in the Eurasian world were always more closely linked to broader contexts (in particular, the offshore power at the other end of Eurasia, still known as the United Kingdom, has no such record of self-contained transformation). Japanese encounters with the outside world during this period may have hastened some turns, but did not affect the main trends in any significant ways. The Mongol invasions in the late thirteenth century weakened the military regime centred in Kamakura, but did not cause its downfall; the rapidly abandoned war of conquest on the Asian mainland at the end of the sixteenth century never amounted to more than a momentary digression from the path of internal state consolidation; the rejection of Christianity in the early sixteenth century was probably more due to fear of its possible use by separatist domain rulers than by any perceived threats from Western Christian power, but the basic shape of the Tokugawa regime was in any case achieved before the persecution was launched.

A further step towards an overall hermetic conception is taken when it is argued that all the transformative developments, those induced by contacts with or challenges from other states as well as those arising from internal dynamics, can be shown to have remained within an enduring and specific cultural framework. For that claim to make sense, the cultural presuppositions will obviously have to be defined in meta-historical and at the same time flexible terms. But the final twist to a hermetic interpretation comes when the continuing and comprehensive cultural pattern is traced back to archaic beginnings.

Eisenstadt's analysis of Japanese civilization takes both these steps: he links its lasting imprint on institutions and practices to indigenous modes of thought that were, as he argues, active at the earliest documented stage of interaction with other cultures and capable of absorbing foreign influences without accepting their most radical implications. But the defining characteristics of this Japanese civilizational pattern can only be fully clarified through contrasting it with a very pronounced alternative, prevalent on the scale of global history. The paradox of a thoroughgoing hermetic approach is that it needs a particularly emphatic version of the comparative one to spell out its conclusions.

Eisenstadt had developed a fully explicit comparative framework before he began to take an interest in the Japanese experience; the main foci of reference were the dominant and durable civilizations of the Eurasian macro-region. But when it came to closer engagement with Japan, he could link up with reflections coming from within, including not least - notably critical appraisals of the Japanese tradition. He refers to Maruyama Masao's work on this subject [Eisenstadt 1996: 7], and Eisenstadt's perspective can plausibly be understood as a radicalization of two key points in Maruyama's diagnosis: the under-structured, syncretic character of the Japanese tradition, and the difficulty of articulating a transcending stance [Maruyama 2006]; a noteworthy corollary of the second point 
is the interpretation of Japanese Marxism as a perceived promise of transcending thought). Eisenstadt's line of argument takes off from the latter theme and transforms it into an indicator of fundamental differences between Japan and the cultural worlds to which it has variously related in the course of a long and entangled history. When Maruyama emphasized the underdevelopment of transcending capacity as a crucial weakness of Japanese thought, he had in mind the predominant traditions of particularism and contextualism; Eisenstadt redefines the problem in terms of a civilizational dimension, attributed to the major Eurasian traditions but supposedly absent in Japan, although the ways of keeping it at a distance and defusing its impact have been distinctive enough to justify the description of Japan as a self-contained civilization - not isolated, but capable of imposing its own terms of contact. The criterion of comparison is a culturally codified ontological principle, a distinction between transcendental and mundane levels of reality, seen as a defining characteristic of civilizational patterns which Eisenstadt calls "axial" and attributes to the cultural worlds most prominent in global history.

The idea of comparing the Japanese historical experience to Chinese, Indian, Islamic and European trajectories is obviously a tempting one, especially when linked to long-term perspectives, but closer examination of terms and presuppositions is needed, and it must begin with questions concerning the concept of axiality. It is based on Eisenstadt's interpretation of the period already known to earlier authors as the Axial Age (dated roughly from the eighth to the third or fourth century BCE), and two steps of definition may be distinguished.The first one posited a cultural common denominator of changes in civilizational centres as different as the ancient societies of Greece, Israel, India and China; this unifying novel feature was a radical ontological dividing line between "transcendental" and "mundane" dimensions of reality, more or less systematically linked to visions of reforming the lower level (more specifically its "human province", to use Elias Canetti's expression) in light of transcendental norms. Such projects resulted in comparable but by no means identical institutional changes. The second step was then a disconnection of the structural perspective from the chronological one; the conceptual focus shifted from an axial period in history to an axial type of civilizations, and the latter category was defined in terms of a capacity for self-reflection and self-transformation on the basis of ultimate and universal principles. Christianity and Islam, emerging as world religions long after the originally circumscribed axial age, then stand out as paradigmatic cases of axiality.

This sweeping generalization across cultural borders imposes limits on further comparison, and it favours - by implication - a certain marginalizing view of Japan. But debates on the axial age and its interpretations have cast doubt on Eisenstadt's constructions [see Árnason - Eisenstadt - Wittrock 2012; Bellah - Joas 2012; Arjomand 2014]. No consensus has developed out of these discussions; the following remarks express the position of the present writer, formulated in greater detail in contributions to the abovementioned collective volumes.

It has proved difficult to confirm claims about a common cultural core of civilizational patterns emerging during the axial age. Scholarship on ancient Chinese thought has, on the whole, not tended to support the case for a distinction and a tension between transcendental and mundane levels of reality; in the Chinese context, transcendence can only be understood in the loose sense suggested by Benjamin Schwartz: "A way of standing back and looking beyond." In the Greek case, the dividing line stressed by Eisenstadt is 
only applicable to a very limited extent, and not linked to the innovations most characteristic of ancient Greek civilization. The reference to a separation of transcendental and mundane realities seems to draw primarily on Judaic and Indian thought, but at the same time to blur the fundamental differences between these two traditions. Furthermore, the institutional innovations in the various axial centres were highly varied; in particular, the paths of state formation differed, not least in regard to imperial ambitions and possibilities. The upshot of closer examination and comparison seems to be that we should think of the axial age as a period of major and exceptionally concentrated transformations, but that the search for a common denominator does not yield anything more specific or uniform than significant changes to the relationship between religion and politics - or, to use an expression that I have proposed elsewhere, to the religio-political nexus [Árnason 2014]. Such changes are important in their own right, but also - in varying degree - because they open up a space for invention in other fields (the development of philosophical reflection, along different lines in Greece, India and China, is a case in point). There is, however, no justification for constructing a model of "axiality" that would enable a projection beyond the original chronological context. These conclusions undermine the idea of a fundamental pattern that would encompass the variety of Eurasian cultural worlds and confine Japan to an atypical periphery. They also suggest that it might be more rewarding to consider successive receptions and transformations of the more or less path-shaping patterns inherited from the axial age, and that would include closer analysis of cross-cultural encounters and engagements in the course of the Eurasian longue durée. But to trace the implications of such a shift for views on Japanese history, we need a more detailed discussion of Eisenstadt's account.

A very significant part of his argument concerns Japanese transformations of cultural themes and religious ideas borrowed from other traditions, especially those that Eisenstadt describes as axial. The chapter on "Some aspects of the transformation of Confucianism and Buddhism in Japan" [Eisenstadt 1996: 219-263] is a systematic and convincing survey of such changes. Eisenstadt argues that "Buddhism, like Confucianism, did not transform the basic premises of the Japanese social organization", and that the internal organization of both these currents took a "familistic and factionalistic direction consistent with the existing frameworks of political struggle" [Eisenstadt 1996: 225]. The upshot was a "far-reaching de-autonomization of their respective organizations and activities and their becoming embedded within existing social frameworks" [Eisenstadt 1996: 228]. Correspondingly, when it came to the defining religious ideas and attitudes, "the major trend was in the immanentist and particularistic direction" [Eisenstadt 1996: 242]. This did not exclude significant new departures, such as the reformist currents in Kamakura Buddhism (thirteenth century) or the recurrent and varying reinterpretations of Confucianism in Tokugawa thought, but Eisenstadt stresses the limited impact and ultimate cultural weakness of these initiatives. Even so, there is no denying the "deepening and diversification of religious consciousness and discourse" [Eisenstadt 1996: 237] that was in the long run achieved; and the line of interpretation so far followed suggests containment and circumscription, rather than complete "Japanization". But Eisenstadt wanted to go one step further, and that is what made him vulnerable to accusations of nihonjinron from the outside. One of the most sweeping but also most cryptic formulations of this additional claim relates to the history of Japanese Buddhism: "What is, however, unique in the case of Japan is that 
its pagan premises, a basically this-worldly religious outlook, have transformed those of a 'great' religion in shaping the tradition of an entire civilization" [Eisenstadt 1996: 235]. Here the term "pagan" is obviously used in the general sense of pre-axial. It remains to be seen where these pagan premises are to be located and identified, and how they have managed to dominate a whole civilization despite its long-term exposure to axial influences.

When Eisenstadt moves to examine "Japanese culture or cultural tradition", he begins with strong statements about "distinctive Japanese conceptions of ontological reality"; they are, most importantly, characterized by "a high degree of mutual embeddedness of what in Western parlance are called nature and culture, that is, a strong sense of the interrelations between the transcendent and the mundane worlds", as well as by "an emphasis on gods as continuous regenerators of the world, but not as its creators" [Eisenstadt 1996: 318]. Further implications are noted, but we need not quote them in extenso; it is, however, worth noting that both a pragmatist attitude to the world and a preference for mythocentric rather than logocentric discourse figure appear among the derivative features. The fundamental premise is a specific cultural ontology.

Eisenstadt proceeds to cite the Kojiki and the Nihongi (referred to above as the Nihon shoki) as the "first fully articulated formulations" of this underlying ontology [Eisenstadt 1996: 319]. In light of the above comments on these two eighth-century texts, some reservations about their capacity to reveal basic, enduring and indigenous cultural conceptions are in order. They are political constructs, geared - each in its own way - to the task of legitimizing the ruling dynasty and its form of sacral monarchy through embedding in a mythological narrative with cosmological connotations. Moreover, they mark a new stage of the comprehensive but politically centred transformation that had been in progress since the turn of the sixth and seventh centuries, and the high point of direct rule by the monarch; this shift involved a violent conflict between two branches of the dynasty. Obviously, the whole enterprise required cultural underpinnings, but the assumption that it rested on a whole inherited world-view and transmitted it unchanged to later generations is unfounded. The context is too intertwined with contingent power struggles, strategies and ideological options for far-reaching conclusions about ontological premises to be plausible.

Eisenstadt was clearly aware of the need to go beyond the reference to canonical texts with a political background; but his main attempt to solve that problem leaves something to be desired. Returning to his claim about persisting conceptions of reality, he notes that they have "often been identified - rightly or wrongly - with Shintoism, that is, with basic ontological beliefs or assumptions that could be better called underlying native orientations" [Eisenstadt 1996: 320-321]. "Rightly or wrongly" suggests some doubts about the equation; but further comments show that he wants to distinguish between changing organizational forms and doctrinal elaborations of Shinto on the one hand, and enduringly underlying orientations on the other. The latter are unequivocally identified with an indigenous mode of thought. "Older Shinto conceptions" [Eisenstadt 1996: 249], "nativist orientations of the Shinto templates" [Eisenstadt 1996: 243] are invoked both to explain the conditional acceptance of Confucianism and Buddhism in the early phase of Japanese history and the limits to new understandings of Confucianism in the Tokugawa era. The implications are clear, and decisive for the idea of Japan as a civilization in its own right: a pre-existing pattern of world articulation guided and qualified the borrowings from other cultural worlds that 
were necessary for the building of a more centred and codified socio-cultural order. However, recent scholarship in this field has increasingly stressed that Shinto as a distinctive religious tradition is the relatively late product of a complex social and cultural history, and cannot be credited with an active role in the transformation that established Japan as a separate part of the East Asian configuration. To quote Herman Ooms, who has done some of the most path-breaking work on this subject, "there is general consensus nowadays that Shintō, as we have come to know it, did not exist at that time, and could not have developed without the appropriation of continental elements, some of them Daoist" [Ooms 2015: 39; on the political and dynastic context, see Ooms 2008].

The reference to Daoism is crucial, and draws attention to a long-neglected aspect of the Sino-Japanese relationship. Eisenstadt did not have much to say on the Japanese response to Daoism; he referred to it as "rejection or dilution" [Eisenstadt 1996: 257], and although he added a long footnote [Eisenstadt 1996: 514-515, footnote 44] admitting that there was more work to be done, that concession did not affect his argument about native orientations. A quarter of a century later, the emerging consensus is that Daoist input, however fragmented, played a key role at crucial moment [see especially the essays collected in Richey 2015]. "Daoism is present as a series of fragments; as elements that inspired and framed cultural and especially political components of the state-building enterprise that occurred in the late seventh and early eighth centuries" [Ooms 2015: 37]; on this view, the inaugural transformation of Japan did not culminate in the Taika reform of 646, as often argued by earlier historians, but somewhat later, during the reigns of Emperor Tenmu and his consort and successor Jito (686-697). It is true and interesting that in the seventh century, an embassy sent by the Japanese ruler explicitly rejected a Chinese offer to send Daoist masters to Japan. But Ooms suggests [2015: 39] that there may have been more to this refusal than meets the eye. In the late sixth century, a Chinese emperor belonging to one of the pre-unification northern dynasties had briefly brought Daoist temples and rituals under direct state control while marginalizing the Daoist establishment. It seems very likely that this precedent was known in Japan, and that the Japanese dynastic strategists preferred to draw their own lessons from an abandoned Chinese past, rather than follow the lead of present and powerful Chinese rulers with a particular interest in Daoism. Be that as it may, the Daoist elements mentioned by Ooms were neither directly related to the texts most representative of Daoism as a philosophical current, nor did they entail any copying of Daoist ways to organize religious life. But there was a background cosmology shared and variously elaborated in philosophical and religious discourses, "a distinctly Daoist-flavored attitude regarding the essential unity of human and cosmos" [Smith 2015: 13]. In the Chinese tradition, this shared imaginary overlapped with the cosmological vision of $y$ in and yang as opposed but complementary principles; under the label onmyōdō, the latter became a key frame of reference for Japanese divination.

The fragmentary borrowings from this broader Daoist culture entered into the mythological pattern built around the newly empowered dynastic state, and into its very elaborate court ceremonies. Ritual was so important for eighth-century Japanese state building that some historians have used the concept of a liturgical state. But there is also evidence of more diffuse popular interest in Daoist cults and deities. Michael Como [2015: 25] refers to "the powerful ritual dimensions inherent in early Japanese responses to a wide array of phenomena such as urbanization, large-scale construction projects, epidemics, the 
transmission and diffusion of medical and engineering technologies, etc.." On this level, the involvement of Daoist fragments seems to have been massive.

This re-evaluation of Daoism in early Japan has major consequences for our understanding of the great seventh- and eighth-century transformation and its historical legacy. It now seems clear that the adoption and adaptation of the Chinese model, initiated and framed (though not totally controlled) by an autonomous political centre that redefined itself in the process, related to all the three currents recognized as components of the Chinese tradition; that the definition of "native orientations" was an outgrowth of this encounter with a more complex cultural world; and that, paradoxically, the ostensibly native patterns owed most to the least clearly visible input from China (on the institutional and explicitly ideological levels, Confucianism and Buddhism had higher profiles than Daoism). This view militates against the notion of Japan as a separate civilization and strengthens the case for considering it as a variant or offshoot of a broader East Asian civilization that we can call Sinic (to borrow a term from Arnold Toynbee and use it in a modified sense, but with appropriate emphasis on Chinese origin and centrality). Among such non-Chinese variants, Japan was clearly the most original, autonomous and enduringly creative. It should of course be added that - as noted above - the role of Korean contacts and immigrants was obviously crucial for the Sino-Japanese connection, but it has proved very difficult to trace this part of the story in detail.

It is not being suggested that the imposition of modified Sinic patterns represented an absolute break. There is no doubt that domestic archaic elements were integrated into the transformative pattern (even in the more dominant Eurasian civilizational centres, radical changes of the kind that Eisenstadt associates with axial breakthroughs were in practice accompanied by compromises), and that various continuities were maintained at the level of folk religion. But no available source or system of traces can justify the assumption of a whole self-contained and self-perpetuating "native" mode of thought. Nor can any pre-existing unity of the Japanese archipelago be taken for granted. The emergence of a new polity with a new cultural framework (sometimes described as the ritsuryo state, with reference to law codes introduced by the architects of the transformation) was also the most decisive step towards the unification of the insular complex called "Japonesia" by a French geographer [Pelletier 1997]. The whole process is best understood as an exceptionally creative encounter; there is hardly another comparable case of a society undergoing such radical change through autonomous adaptation of a foreign model. If we want a closer view of the original features involved in this civilizational transfer, we should start with the most visible connection between culture and politics, rather than an apparent cultural primordiality that turns out to be derivative.

The crucial point is the construction of sacral rulership. Historians have often noted the specific Japanese twist to that part of the Chinese model. It is now generally agreed that the title tennō was first used by Emperor Tenmu, and that it was an adaptation of occasional Chinese usage with Daoist connotations [Ooms 2015]. More importantly, the Japanese redefinition of supreme authority resulted in a major deviation from the Chinese tradition: the "mandate of Heaven" claimed by successive Chinese dynasties was replaced by the myth of divine descent, attributed to the one and only dynasty that was in power at the time of the great transformation and retained its symbolic status forever after, notwithstanding major changes to the power structures. If the religio-political nexus is to be 
seen as a central constituent of the socio-cultural world [Árnason 2014], this particular version of it calls for a closer look at contextual impact and long-term implications. The genealogical continuity between divine and human ancestors, extended to living rulers, lent support to - and was in turn supported by - more general notions of ontological continuity between different realms of reality; a certain affinity with the interpretive pattern that Eisenstadt ascribed to Japanese civilization can thus be explained in more historical terms. Some criticism has been levelled at "big bang theories", crediting the imperial court and its ideologists with implausible power to restructure a whole cultural framework. However, historical evidence suggests that the emerging centre had indeed achieved an exceptional capacity to impose a new order. And in so doing, it could draw strength from more diffuse currents. There are good reasons to assume that the spread of a de-institutionalized Daoism, with a proliferating collection of deities and visions of multiple correspondences and continuities between human and cosmic reality, was of major importance for the transformative process. It is a well-established fact that the ascendancy of Buddhism during the eighth century overshadowed the Daoist aspects of religious life and court ideology, but they survived in more latent form, not least inside varying branches of Buddhism.

\section{Politics and Religion: Maruyama’s Perspective}

The seventh- to eighth-century transformation is, for a variety of reasons, a key episode in Japanese history. It created a political order that proved highly resilient and gave rise to a cultural legacy of lasting significance. From a more long-term point of view, it can be seen as a starting-point for far-reaching changes in later centuries. Finally, the ideological and institutional reinterpretation of the Chinese model could be turned into a paradigm for other projects of autonomous learning from foreign experience, real or envisaged (recent variations on this theme are discussed in Mishima Kenichi's contribution to this issue).

An interesting view of early Japanese prefigurations was proposed by Maruyama Masao [1988]. His essay on matsurigoto, a traditional term which he translates as "matters governmental", belongs to a late stage of his work and reflects a certain disillusionment with the modernizing efforts of Japanese political thought. He had become aware of what he called the "basso ostinato of Japanese political life", and hoped to clarify its nature by examining the "recurrent patterns of thinking" [Maruyama 1988: 28] that manifested themselves through the modifications of ideologies imported from the Asian continent or the West. Although the affinity with Eisenstadt's argument is obvious, this continuity of responses is not quite the same thing as a self-perpetuating mode of thought. We might say that Maruyama leaves open the question whether the "basso ostinato" is invented simultaneously with the first major adoption of foreign models, or grounded in pre-existing cultural patterns.

Maruyama examined the eight-century political vocabulary (there are no comparable sources of earlier origin) and singled out matsurigoto as the most revealing term; but he rejected the interpretation - current among prewar Japanese nationalists and apparently first defended by advocates of imperial restoration in the fourteenth century - that took this word to justify the equation of political and religious affairs. Sacral connotations of matsuri were invoked to back this claim. Maruyama quoted the eighteenth-century master thinker of nativism, Motoori Norinaga, in support of another reading; this is all the more 
remarkable since Norinaga had also been cited as an authority by the ideologists of religio-political unity. But as Maruyama shows, the textual sources clearly indicate a different meaning: matsurigoto "implies offerings and services" to a superior [Maruyama 1988: 29, quoting Norinaga's commentary on the Kojiki]. However, the ultimate human superior was the emperor, who in turn served the gods, and this connection links the notion of matsurigoto - as Motoori explicitly states - to the idea of "government under heaven". In the final instance, we are thus dealing with a religio-political nexus, but of a more flexible kind than imagined by latter-day religious nationalists, and with the specific twist that "government was defined not so much in terms of the rulers, as in terms of the subordinates" [Maruyama 1988: 33], those who offer services.

The most interesting part of Maruyama's argument is the suggestion that "a paradigm ... based upon the political vocabulary of the eighth century ... is crucial to the understanding of the political dynamics of later periods" [Maruyama 1988: 28-29]. This longterm interpretive impact is, in the final instance, due to "the separation of the level of legitimacy from the level of actual power" [Maruyama 1988: 38]. Admittedly, the culminating phase of the eighth-century reforms was marked by the direct personal rule of a strong emperor, but the devolution of power began very soon after that and very close to the centre; that trend was already obvious in the invention of a new institution, a governmental council (daijōkan) meant to function as an intermediary between the emperor and the bureaucratic apparatus. This was already a significant addition to the Chinese model. Further shifts were at first contained within court society, where the rise of the Fujiwara family led to a major rearrangement. In the longer run, the devolutionary trend was - as Maruyama saw it - taken to much greater lengths: "Power developed downward as it became more informal and private. The climax of this convergence was ge-koku-jo, or inferiors overpowering their superiors, a phenomenon which characterized the fifteenth and sixteenth centuries when poweful local warriors rose to power and chaos prevailed. The remarkable thing, however, is that no matter how extreme ge-koku-jo may have been, it never led to any change in the level of political legitimacy in Japan as a whole" [Maruyama 1988: 41-43]. To underline the latter point, he adds that the emphasis on politics as doing ritualized service to superiors, together with the separation of legitimacy from effective power, made it difficult to conceive of revolutionary change.

This line of argument merits some further comments. Maruyama was not proposing a culturalist and monocausal explanation of the whole development that gave rise to feudal power structures and military government, theoretically legitimized by a powerless imperial dynasty. The transformation of Japan between the late eighth and the early seventeenth century was a complex social process, involving a variety of forces, and its key aspects - the empowerment of provincial officials and warriors, the crises that paved the way for the establishment of new power centres, and the extreme fragmentation around 1500, followed by unification under military rule - can only be explained in terms of multiple factors. Maruyama's point is, to rephrase it in slightly different words, is that the causal network included an established cultural definition of power, conducive to devolution and informalization, but also to the perpetuation of existing ways to legitimize rule. Cultural presuppositions thus facilitated the redistribution of power in two complementary respects: they licensed downwards shifts and discouraged open breaks with tradition. This is a view rather reminiscent of Weber's comment about ideas channelling interests (power struggles 
are a prime example of interests in conflict), with the added twist that the dynamic of changing power balances reveals logical but unintended implications of guiding ideas. There is no doubt that the architects of the ritsuryo state regarded the divinization of the dynasty as an empowering move, but it turned out to favour the disconnection of power and legitimacy. The exalted sacral status of the ruler made it easier to minimize his involvement in worldly affairs.

\section{Cultural Orientations and Political Transformations: Notes for Further Discussion}

Maruyama's search for connections between archaic and early modern Japan, based on a mutually transformative intertwining of cultural meanings and power structures, suggests a more general point to be raised against Eisenstadt's interpretation of Japan. At the beginning of a chapter on Japanese institutional dynamics, he poses the question of "relations between culture, social structure and historical contingency" [Eisenstadt 1996: 345]. The matter to be clarified is, in other words, the impact of ontological presuppositions, discussed in the preceding chapters and equated with a native mode of thought, on the institutional sphere. Eisenstadt's answer is a list of "elective affinities or homologies" between "the strong immanentist ontological conceptions and the mode of definition ... of the major social actors, the arenas of social action, and the Japanese collectivity" [Eisenstadt 1996: 345]. Here I need not reproduce it in toto, but the key features are easily summarized. They have to do with this-worldly "vitalistic and activist components", with a "centrality of mythic, non-discursive - as against logocentric orientations", and "flexible movement between different contexts", which also entailed "openness to change and to external influences" [Eisenstadt 1996: 345-346].

The problem with this approach is not primarily about the validity of specific points; they are indeed based on a wide range of concrete examples. It is more a matter of the overall perspective and its implications. The relationship between cultural ontology and institutional arenas is theorized in terms of durable affinities, rather than historical dynamics. That line of analysis is at odds with Eisenstadt's general emphasis - in theoretical texts as well as in other case studies - on institutional dynamics and their transformative impact. Not that his interpretation of Japan ignores historical transformations: the second part of the book discusses Japanese feudalism, the Tokugawa state and the "revolutionary restoration" of the Meiji era. But these chapters are followed by closer examination of a supposedly indigenous and stable civilizational framework; the final conclusions are therefore more suggestive of civilizational containment than of any civilizational factors conducive to change. This is a logical consequence of the line taken on Japan as a distinctive civilization with an indigenous and enduring mode of thought. To conclude the present discussion, I will suggest some ways of linking the alternative defended above - a more historical conception of Japanese variations on shared East Asian civilizational thems of Chinese origin - to dynamics of socio-cultural change. The processes in question are, in the final instance, "articulations of the Sinosphere", to use Joshua Fogel's term [Fogel 2009]; but here I will limit the overview to early and advanced modern developments that already presuppose a long history of internal Japanese articulations.

The rearticulation now commonly seen as the genesis of early modern Japan was a twofold one. A unification of power structures after a period of extreme fragmentation 
went hand in hand with a reconnection to cultural sources of legitimacy; neither of these processes could be completed without institutional innovations, but those who emerged as architects of a new order strove to maintain an appearance of re-traditionalization. Whether the conflicts and upheavals of the sixteenth century could have taken another course is a tempting question for exercises in alternative history, perhaps the most interesting of its kind in the Japanese historical record, but will not be pursued here. What matters for our purposes is the very forceful, comprehensive and long-lasting settlement that was imposed.

The disintegration of central power structures in the wake of the Onnin war (14671477) led to a proliferation of smaller units ruled by local military dynasties and locked in perpetual warfare. In some cases, the ruling families implemented "house codes" that may be seen as guidelines for state building on a small scale, and the most elaborate among them show a strong emphasis on the rationalization of practices and resources [Ooms 1989: 23-25]. But there was no direct road from these experiments to a reunified state. The fluctuating power wielded by rival daimyō families had to be concentrated and redefined in relation to surviving symbols and embodiments of supreme authority. At the same time, the military elite and those who aspired to lead it had to face a new challenge from a social force that had taken advantage of the space opened up by the fragmentation of power; a coalition of Buddhist monasteries and village communities, known as $I k k \bar{o}-i k k i$, was by the middle of the sixteenth century a major contender for hegemony in the central regions. Although this constituted a significant redistribution of social power, the $i k k \bar{o}-i k k i$ bloc cannot be reduced to a peasant movement; leadership was firmly held by a dominant Buddhist monastery, and the dynamic of the movement seems to have tended towards a Buddhist notion of sacral kingship, comparable to the emperor in Kyoto but not taken to the level of direct confrontation [Ooms 1989: 29-39; see also McMullin 1984].

The successive strategies of the three "unifiers" - Oda Nobunaga (1534-1582), Toyotomi Hideyoshi (1537-1598) and Tokugawa Ieyasu (1543-1616) - took off from this constellation, confronting the $I k k \bar{o}-i k k i$ on the battlefield and engaging in complex manoeuvres $v i s-\grave{a}$-vis the imperial court. Following Ooms's analysis [Ooms 1989: 18-62], it seems that the sequence of three bids for supreme power began with an implicit deviation from traditional patterns and ended with a unilateral settlement that left the symbolic status of emperor and court untouched but codified a total transfer of power to the victor of a final showdown within the military elite, who then proceeded to impose a regime of strict control on both allies and defeated adversaries. Nobunaga, who made the most decisive moves but was killed before he could claim complete success, projected an image of himself as a divinized autocrat, apparently in response to his Buddhist opponents; he did not insist on this in dealings with the imperial court, but resisted attempts to integrate him into the system of court titles, and the most plausible account of this episode is that the relationship between traditional authority and ascendant power was at a crossroads, with very different possibilities open and the main protagonists as yet uncommitted to clear options. Hideyoshi retained the self-divinizing strategy, but with a new emphasis on integrating it into a Shintō framework. He is known to have - in official correspondence - described religious traditions of other countries, Buddhism and Confucianism in particular, as offshoots of Shintō; this was obviously linked to his vast expansionist ambitions, not shared by the other unifiers and never justified in realistic terms. 
Ieyasu, who presided over the last phase of unification, toned down the idea of self-divinizing (he arranged for a posthumous cult of himself as a Shintō deity); more importantly, and contrary to his predecessors, accepted the title of shogun, bestowed by the emperor and already a strong symbol of traditional legitimacy; but care was taken to minimize any implications of delegated power. Ieyasu soon sidelined the title by transferring it to his heir; he claimed a direct sacral affiliation with the "way of heaven"; and he claimed authority to regulate the life of the Kyoto court. In brief, the settlement that accompanied final unification was marked by a double emphasis: on the avoidance of a break with the imperial centre and its traditions, and on the unconditional power of the new centre established alongside it. This outcome of an ambiguous process rested on a pragmatic adjustment of meanings, rather than a coherent programme. To put it another way, the reintegration of politics and culture involved agency and decision, and cannot be reduced to a self-perpetuating civilizational logic. But the result was of civilizational significance: "Military power, the naked instrument of domination, was transubstantiated through association with the sacred into political authority of a religious character" [Ooms 1989: 61].

The historical details recapitulated above are important for the understanding of later developments. Tokugawa Japan was a very ingeniously constructed and structurally resilient polity, but there were limits to unity and potentials of subversion, inherent in the very pillars of the regime; they were kept in effective check for a long time, but in the end, their joint impact proved fatal. Three factors of this kind deserve particular mention. Although the paradox of the powerless but ritually sovereign imperial institution was not directly explosive, it offered an opening for those who might - with backing from elsewhere - be able and willling to challenge the Tokugawa settlement. At another level of the power structure, the autonomy left to the feudal domains and their hereditary rulers could become a basis for strategies and alliances directed against the centre; this systemic risk was neutralized by an elaborate machinery of control, but never eliminated. Finally, the Tokugawa founders opted for an eclectic ideological framework, accommodating Confucianism, Buddhism and Shintō. Earlier notions of a Neo-Confucian orthodoxy based on a Chinese model have been decisively refuted by recent scholarship, most systematically by Ooms. The officially accepted pluralism opened a certain space for innovation; as historians of Tokugawa thought [especially Maruyama 1974 and Watanabe 2012] have shown, elements of critical reflection on social and political problems can be found in various currents active from the seventeenth to the nineteenth century, but it was the nativist thought developed by the kokugaku school (associated with but not reducible to the Shintō revival) that proved most consequential.

Around and after the middle of the nineteenth century, more precisely during the exceptionally eventful period known as bakumatsu (1853-1868), the three abovementioned factors fused in a way that brought Tokugawa rule to an end. A coalition of forces spearheaded by samurai activists from the domains of Satsuma and Chōshū allied with court nobles advocating a return to the principle of direct imperial rule and mobilized broader support among circles influenced by nativist thought; there was no mass mobilization on a scale comparable to the paradigmatic Western revolutions, but the nativist imaginary and its ideological expressions helped to link the mythology of the imperial institution to an emerging nationalism of more modern kind. This transformative convergence was not predetermined by any systemic logic. To quote Max Weber, it must be 
explained in terms of a "concatenation of circumstances". Conrad Totman's very detailed and documented history of early modern Japan places a strong emphasis on the ecological background; on this view, rapid economic and demographical growth in the isolated archipelago led to a depletion of resources that made later Tokugawa times very different from the seventeenth-century efflorescence; a "period of stasis" set in around 1710 [Totman 1993, especially 235-279]. While the stark distinction between growth and stasis is to some extent a matter for debate, there is no doubt that the unusual pattern of high but geopolitically contained growth, accompanied by sustained urbanization, resulted in environmental problems that affected the resource basis of the regime and its scope for action. But more direct and visible reasons explain why the de-stabilizing factors came together and caused a rupture when they did. On the one hand, the threat of foreign intervention, beginning with the arrival of American warships in 1853, provoked resistance, fragmented at first but then - after some complications - unified around the vision of radical social and political change as a precondition for retaining national independence. On the other hand, the fact that this project was turned against the Tokugawa regime must be seen in the context of the latter's own record of attended and proclaimed reforms. The history of Tokugawa Japan included successive episodes of reform, with some input from intellectual currents; the most notable was probably the Kyōhō reform (1716-1735). No proposal to alter the fundamentally hierarchical order of society was ever on the agenda, but there were serious efforts to improve administration, economic performance and living conditions. The last of the reform projects, initiated by the Tokugawa councillor Matsudaira Sadanobu at the end of the eighteenth century, was also the most conservative; among other things, it included an unprecedented (and ineffective) ban on heterodoxy. But looking at the record as a whole, a periodically reaffirmed claim to reforming capacity seems to have been part and parcel of the social imaginary that sustained Tokugawa rule. It cannot be said that such inclinations had wholly disappeared in the 1860s. A last-minute reform programme was adumbrated by the Tokugawa centre before its demise, and its partisans put up some resistance to the victorious opposition. But what counted was the appeal to broader perceptions. The bakufu was seen as an exhausted institution, discredited by its inability to resist Western intrusions, and it had no alternative to the myth of imperial restoration as a bridge between tradition and nationalism.

\section{Meiji Japan and beyond}

A new phase of Japanese modernity began in 1868; if we describe it as advanced, that should not be taken as an unqualified affirmation of progress; rather, the point is that it was characterized by an acceleration of trends defining the modern condition and an opening of larger spaces for their unfolding. From now on, further transformations of Japanese culture, society and politics took place in close and continuous interaction with a global environment, and they were not pre-structured by stable cultural premises. On this issue, Eisenstadt's general descriptions are unobjectionable: "This period was characterized by many uprisings - those of Tokugawa loyalist peasants, local Buddhist priests, dislocated samurai groups, and more modern popular movements such as the Citizen Rights ... The relatively coherent policies that developed in this period of trial and error, toward the end of the 1890s, crystallized to a large extent in response to trends and movements seen by 
the Meiji elite - the so-called oligarchs and the slowly emerging bureaucracy - as threats to national unity and cohesion and, consequently, to international standing" [Eisenstadt 1996: 25]. The ideological framework of this consolidation is described in the following terms: "This ideology did not emerge automatically as a sort of natural continuation of Japanese tradition, even if its crystallization was in many ways reminiscent of that of the Tokugawa ideology, especially in the ways both transformed the same components of Neo-Confucianism" [Eisenstadt 1996: 33]. Given the distinctive prelude to the constitution of Tokugawa ideology, discussed above, and the militantly nationalist character of the Meiji "civil religion" (Eisenstadt also used that term), the comparison seems dubious. But more importantly, the emphasis on changing approaches, conflicts and politically enforced solutions casts doubt on the strong assumptions about civilizational continuity, inherent in the conception of enduring pre-axial patterns. Admittedly, it may seem tempting to take the cultural closure imposed by ultra-nationalism as evidence of such a continuity. But the closure was never anywhere near what its most extreme advocates wanted (John Krummel's contribution to this issue is instructive in that regard; the event that it describes exemplifies both the constraints of wartime politics and the enduring pluralism of intellectual life). Moreover, a nationalism that was - because of Japan's involvement in world politics - forced to confront global ideologies found itself in a situation different from traditional precedents. In that context, one critical observation should be recorded: Eisenstadt's analysis of Japanese modernity has surprisingly little to say about Japanese colonialism and its head-on collision with Western powers; it ended in self-destruction, but the consequences were massive and must be seen as a key aspect of Japan's imprint on global history.

That said, there is no denying that Eisenstadt has made a strong case for Japan as a particularly prominent example among multiple modernities, and the reasons have to do with a long-term historical trajectory as well as traditions that bear some traces of early beginnings. When it comes to chronological demarcation, the direction taken after 1868 seems continuous enough - despite uncertainties in the early decades and political shifts after World War I - to refer to the period from 1868 to 1945 as Meiji Japan and characterize it as a distinctive stage in the history of Japanese modernity. This periodization is, among other things, relevant to the question of Japanese fascism. There is no consensus on this issue among historians, but the arguments against the notion of a Japanese fascism seem stronger than those of the other side. Despite undeniable affinities between the wartime Japanese regime and its European allies, the former lacked some of the features that had been crucial to the rise of fascism in Europe: there was no mass movement with paramilitary offshoots, no charismatic leader, and no ideology of radical political transformation (the extreme nationalists who called for closer unity of emperor and people were too traditionalistic to fit into that category). What did characterize the Japanese situation was a constellation of partial fascist influences, significant in their own right but not adding up to a coherent overall pattern. The reform buraucrats who played a central role in empire building (not least in the contruction of a showcase puppet state in Manchukuo) and preparation for war were influenced by European fascist regimes, though more by perceptions of their practices than by their ideologies. This part of the story has been analyzed in detail by Janis Mimura; however, reservations may be made about her concept of techno-fascism, defined as "a new form of authoritarian rule in which the 'totalist' state 
is fused with the military and bureaucratic planning agencies and controlled by technocrats" [Mimura 2011:4]. This is a convincing summary of the aims pursued by the reform bureaucrats, but if we prefer a historically specific concept of fascism (and there are good reasons to insist on that, against the all too common indiscriminate use), the absence of the abovementioned factors speaks against the amalgamation posited by the notion of techno-fascism. Another instance of limited affinity with fascism was the case of the extremist officers who attempted (and botched) a coup in 1936. Finally, intellectual life in the years between World War I and the 1945 collapse took some surprising turns, and there were even thinkers with Marxist connections who showed interest in fascist ideas. All things considered, then, the Japanese points of contact with European fascism were partial and disjointed.

If 1945 was a particularly obvious end of an era, it is proving much less straightforward to agree on a defining label for postwar Japan. Three or four decades ago, economic exceptionalism seemed the most plausible approach to that question, and the most seminal work in that vein was Chalmers Johnson's book on the Japanese miracle [Johnson 1982]. Its key to post-imperial Japanese history was the concept of the capitalist developmental state; Johnson took care to emphasize the capitalist context, but this has not always been duly recognized in later debates on the developmental state. He focused on a multi-faceted cooperative relationship between the public and the private sector, which he also characterized as a rational version of economic planning, in contrast to the irrational planning practiced in Soviet-type economies. His analysis stressed the need for an institutional explanation; that ought to have made the book interesting for a theorist of Japanese civilization, but Eisenstadt only mentions it in passing, without any discussion of its argument.

Later difficulties of the Japanese economy, increasingly evident from the 1990s onwards but rooted in older problems, have led to more sceptical views on the developmental state, and even to dismissive conclusions about its record. No detailed discussion of these matters is possible within the limits of the present paper, but a few concluding remarks on ways of posing the problems may be added. In the first place, recent troubles are not a valid reason for downplaying the real achievements of the high-growth period. A historical perspective on postwar Japan, especially one with comparative aims, must acknowledge "the overall transformation of the country from a ruined, bombed-out shell to the world's number two industrial and economic power", as well as the fact that this happened "in a demonstrably peaceful society with free elections and free speech" [Taggart Murphy 214: 95]. It is not uncommon for patterns of social practices to enter a phase of diminishing effect - or even structural crisis - after prolonged success. When dealing with such cases, historical sociology will insist on close attention to specific contexts and avoidance of onefits-all explanations; by the same token, doubt is in order when a particular sector of social life is separated from broader interconnections and its supposedly systemic logic assumed to account for changing fortunes. In the case at hand, the domain directly concerned is the economy, and economics is - among the social sciences - notoriously most attracted to streamlined explanations. The economic scheme that appears to fit the Japanese case best is the idea that institutions and policies geared to catching up with more advanced countries will prove less suitable after that aim has been achieved. Richard Katz's book on "the system that soured" [Katz 2001] is the most systematic elaboration of this argument, but it has also been invoked by more popular commentators. An obvious objection is that the Japanese 
"miracle", as it was widely labelled, was no ordinary catch-up; both the extreme desolation from which the postwar recovery started and the exceptional position that Japan came to hold in world economic affairs set this case apart from others. At the height of success, the Japanese economy appeared as an effective and in some striking ways superior rival to the West on the latter's own ground. The fears of a coming Japanese hegemony were never realistic, but there was a genuine shift in the relative weight of varying capitalisms, and that calls for examination of specific causes and preconditions. Johnson's institutional perspective is still relevant, but may need more emphasis on complementary factors. Taggart Murphy [2017: 97-98] argues that institutional explanations were obstructed "by various ideologically motivated Japanese attempts to place some of these institutions beyond investigation by assertions that they resulted not from conscious political design but were inimitable outgrowths of Japanese culture". The idea of $i e$ society as a civilization, discussed and criticized in Mishima Kenichi's contribution to this issue, is a case in point; it was no doubt overstretched, but ie as an organizational principle (commonly translated as "house" in the sense of a kinship unit, or - as in this case - constructions modelled on such units) did exist in the Japanese tradition, and does seem to have been made some use of in the structuring of economic life. There were no simple outgrowths of culture, but there could through conscious design - be reactivations and adaptations of traditional forms.

Another contextual factor was the double-edged relationship to the United States. On the one hand, the conversion of the militaristic imperial state into a developmentalist one, with a focus on the accumulation of economic power, maintained bureaucratic rule in a new context and thereby helped to minimize the impact of the constitutional reforms imposed by the US occupation authorities. On the other hand, the alliance negotiated after the occupation ensured privileged access to the US internal market; as Gary Hamilton and Solee Shin [2015] have shown, this meant that structural changes to US retail trade became a major boost to economic growth in Japan (and other East Asian countries).

A further argument against oversimplified accounts of Japan's journey from triumph to troubles is the complicated sequel to the period of highest growth. There was no straightforward descent into stagnation. What happened in the late 1980s "was, in many respects, the greatest financial bubble ever" [Taggart Murphy 2017: 178]; it is now unanimously regarded as a prelude to the protracted crisis of later decades, but at the time, it could because of Japan's reinforced presence on international financial markets - be mistaken for a new dimension of growth; quite a few observers shared that view. In retrospect, and with particular reference to the financial crisis that shook the world in 2008 and the following years, it seems clear that the Japanese bubble should be seen in a global context and as an early example of trends subsequently active on a much larger scale. Problems related to global financialization and its diversified impact are the cutting edge of present comparative research on capitalism, but those who have attempted synthesizing work in that field are on the whole not very interested in the Japanese experience.The most ambitious and acclaimed history of the financial crisis [Tooze 2019] has next to nothing to say on Japan. On the other hand, some studies of the Japanese bubble and the following recession have developed ideas suggestive of broader application. Bai Gao set out to analyze the consequences of the Japanese encounter with two major changes to the dynamics of global capitalism. The Japanese model, perfected in the 1960s, was based on strong coordination of state, banks and corporations; the changes were "the shift in the cycle of capital 
accumulation from the expansion of trade and production to the expansion of finance and monetary activity, and the shift in the major policy paradigms of advanced capitalist economies from social protection to the release of market forces" [Gao 2001: 7]. Richard Koo [2009] coined the concept of "balance sheet recession", referring to high levels of debt in the private sector and efforts to reduce them, rather than maximize profits; he saw this as a key cause of the long stagnation after the bubble and suggested that it might also apply to major recessions in Western economies.

All the above considerations suggest that an analysis of Japan's "post-miracle" economic trajectory demands close attention to multiple contexts, and that means interdisciplinary perspectives of a kind not easily achieved. Among relevant publications, T. J. Pempel's account of a "regime shift" represents a noteworthy pointer in that direction. He defines a political-economic regime as follows: "A regime is composed of three essential elements: socioeconomic alliances, political-economic institutions, and a public policy profile. These three overlap and reinforce one another", he then adds a comment underlining the historical character of all three: "Coalitions and alliances come and go; institutions are born and swiftly die; policy directions shift like the wind" [Pempel 2000: 20]. This emphasis on transience does not prevent the author from recognizing "long continuities", but his point - explicitly related to Japan - is that they can only be grasped in interaction with more or less radical shifts. The upshot is that each of the "three essential elements" has broader historical implications, and for a proper assessment of them, we need comparative approaches. To the best of my knowledge, there is still no work that could be credited with a major breakthrough along these lines. To put it another way: while it is clearly the case that Johnson's model of the developmental state is no longer applicable to contemporary Japan, it has so far not been replaced by any comparable combination of conceptual insight and empirical grounding. But if we want to conclude with a shorthand description, a quote from one of the most detailed studies is probably still apposite: "The Japanese model is changing, but the transition is continuous rather then discontinuous. For practical purposes, it is impossible to identify a clean break ... Likewise in the future, we are not likely to see an end to the Japanese model but only its continuous redefinition" [Vogel 2007: 224]. This seems consistent with a more recent portrayal of the Japanese state as still undergoing a "neo-liberal hybridization of the developmental state" [Suzuki 2014]. No case has been made for this process having reached a final stage.

\section{Bibliography}

Arjomand, Said (ed.) [2014]. Social Theory and Regional Studies in the Global Age. New York: SUNY Press.

Árnason, Jóhann P. [2014]. The religio-political nexus: Historical and comparative reflections. In. Árnason, Jóhann P. - Karolewski, Ireneusz Pawel (eds.). Religion and Politics. European and Global Perspectives. Edinburgh: Edinburgh University Press, pp. 8-36.

Árnason, Jóhann P. - Eisenstadt, Shmuel N. - Wittrock, Bjőrn [2012]. Axial Civilizations and World History. Leiden - Boston: Brill.

Bellah, Robert - Joas, Hans [eds.] [2012]. The Axial Age and its Consequences. Cambridge/MA: Harvard University Press.

Como, Michael [2015]. Daoist deities in ancient Japan: Household deities, Jade Women and popular religious practices. In. Richey, Jeffrey L. (ed.). Daoism in Japan.Chinese Traditions and their Influence on Japanese Religious Culture. London: Routledge, pp. 24-36. 
Dower, John [1999]. Embracing Defeat. Japan in the Wake of World War II. New York: W.W. Norton.

Eisenstadt, Shmuel N. [1996]. Japanese Civilization. A Comparative View. Chicago: The University of Chicago Press.

Fogel, Joshua A. [2009]. Articulating the Sinosphere. Sino-Japanese Relations in Space and Time. Cambridge/ MA: Harvard University Press.

Gao, Bai [2001]. Japan's Economic Dilemma. The Institutional Origins of Prosperity and Stagnation. Cambridge: Cambridge University Press.

Hamilton, Gary - Shin, Solee [2015]. Demand-responsive industrialization in East Asia. European Journal of Social Theory 18 (4): 390-412.

Johnson, Chalmers [1982]. MITI and the Japanese Miracle. Stanford: Stanford University Press.

Katō, Shuichi [1990]. A History of Japanese Literature, v. 1: The First Thousand Years. Tokyo: Kodansha International.

Katz, Richard [2001]. Japan, the System that Soured. London: Routledge.

Kershaw, Ian [2008]. Fateful Choices. Ten Decisions that Changed the World, 1940-1941. London: Penguin.

Koo, Richard C. [2009]. The Holy Grail of Macroeconomics. Lessons from Japan's Great Recession. Singapore: Wiley.

Lévi-Strauss, Claude [2011a]. L'anthropologie structurale face aux problems du monde moderne. Paris: Seuil.

Lévi-Strauss, Claude [2011b]. Lautre face de la lune. Écrits sur le Japon. Paris: Seuil.

Lie, John [2001]. Ruth Benedict's legacy of shame: Orientalism and occidentalism in the study of Japan. Asian Journal of Social Science 29 (2): 249-261.

Maruyama, Masao [1974]. Studies in Intellectual History of Tokugawa Japan. Princeton: Princeton University Press.

Maruyama, Masao [1988]. The structure of Matsurigoto: the basso ostinato of Japanese political life. In. Henny, Sue - Lehmann, Jean-Pierre (eds.). Themes and Theories in Modern Japanese Histories. London: Athlone Press, pp. 27-43.

Maruyama, Masao [1995 (1963)]. Thought and Behaviour in Modern Japanese Politics. New York: Columbia University Press.

Maruyama, Masao [2006]. Denken in Japan. Berlin: Suhrkamp.

McMullin, Neil [1985]. Buddhism and the State in Sixteenth-Century Japan. Princeton: Princeton University Press.

Mimura, Janis [2017]. Planning for Empire. Reform Bureaucrats and the Japanese Wartime State. Ithaca: Cornell University Press.

Mouer, Ross - Sugimoto, Yoshio [2015(1986)]. Images of Japanese Society. A Study in the Social Construction of Reality. London: Routledge.

Ooms, Herman [1989]. Tokugawa Ideology. Early Constructs, 1570-1680. Princeton: Princeton University Press.

Ooms, Herman [2008]. Imperial Politics and Symbolics in Ancient Japan. The Tenmu Dynasty, 650-800. Honolulu: University of Hawaii Press.

Ooms, Herman [2015]. Framing Daoist Fragments, 670-750. In. Richey, Jeffrey L. (ed.). Daoism in Japan. Chinese Traditions and their Influence on Japanese Religious Culture. London: Routledge, pp. 37-59.

Pelletier, Philippe [1997]. La Japonésie. Géopolitique et géographie historique de la surinsularité au Japon. Paris: CNRS.

Pempel, T. J. [2000]. Regime Shift.Comparative Dynamics of the Japanese Political Economy. Ithaca: Cornell University Press.

Richey, Jeffrey L. (ed.) [2015]. Daoism in Japan. Chinese Traditions and their Influence on Japanese Religious Culture. London: Routledge.

Smith, Jonathan [2015]. Pleiades retrieved: A Chinese asterism's journey to Japan. In. Richey, Jeffrey (ed.). Daoism in Japan. Chinese Traditions and their Influence on Japanese Religious Culture. London: Routledge, pp. 11-23.

Souyri, Pierre [2010]. Nouvelle Histoire du Japon. Paris: Perrin.

Suzuki, Takaaki [2014]. L'hybridation néolibérale de l'État développeur japonais. Critique internationale 63: $19-40$.

Taggart Murphy, R. [2014]. Japan and the Shackles of the Past. New York: Oxford University Press.

Totman, Conrad [1993]. Early Modern Japan. Berkeley - Los Angeles: California University Press. 
Vogel, Steve [2007]. Japan Remodeled. How Government and Industry are Transforming Japanese Capitalism. Cornell University Press.

Watanabe, Hiroshi [2012]. A History of Japanese Political Thought, 1600-1901. Tokyo: International House of Japan.

Jóhann P. Árnason, born 1940 in Iceland, studied philosophy, history and sociology in Prague and Frankfurt. He taught sociology in Heidelberg and Bielefeld from 1972 to 1975, and at La Trobe University in Melbourne, Australia, from 1975 to 2003. He is now emeritus professor of sociology at La Trobe University and a founding faculty member of the Department of historical sociology at Charles University in Prague. His research interests centre on social theory and historical sociology, with particular emphasis on the comparative analysis of civilizations. 